\title{
HERLeadership: Addressing the Continued Lack of Women in Leadership
}

\author{
Brandy Doan \\ University of Windsor \\ Lindsey Jaber \\ University of Windsor
}

In this conceptual paper, we argue for theory adaptation of the K-12 educational leadership framework in Ontario, Canada. We propose that leadership characteristics, skills, values and behaviours for women and equity-seeking groups differ from traditional white, male-oriented leadership expectations. As an illustrative example, one recent study of women principal's experiences in leadership in one school district in Ontario is discussed. We further compared leadership behaviours of women from three different studies and found that authentic school leadership differs from the current leadership expectations that are identified and valued in Ontario. Leadership frameworks that are devoid of anti-racist, anti-oppression concepts and language fail to challenge norms and address concerns about power, discrimination, ethics, and organizational politics. Without addressing identity in leadership, organizational equity, diversity and inclusion strategies remain performative, create barriers, and possibly exacerbate gender and racial disparities.

Keywords: leadership, K-12 education, feminism, gender, race, identity, equity

\section{INTRODUCTION}

Women comprise half of the workforce, and recently, now outpace male academic achievement (McRae \& Dias, 2014). The World Economic Forum published the Gender Gap Report in 2021, which is an analysis of statistics and survey data collected from international organizations from 156 countries. Across the globe, there is still a $32.2 \%$ average gender gap that remains to be closed for women. Why do such cavernous disparities continue to persist so much so that the World Economic Forum predicts that by taking all the countries into account, true gender equality is projected to take an average of 135.6 years to achieve?

The Canadian Women's Foundation (2019) shares national statistics about women at work. Women continue to earn 76.8 cents to every dollar men earn. For women who are racialized, Indigenous, living with a disability or are new to Canada, this gap is even greater. Women who have the same education, experience, and socio-demographic background earn $\$ 7,200$ less than male counterparts. Female CEOs earn $\$ 46,500$ less than male colleagues in the same roles, and receive larger payouts on average, $\$ 15,210$ per year than men do (Gender and Economy, 2020). 
In the field of K-12 education, leadership paradigms were created by white men, for white men, and leaders of all identities continue to be compared against these theories and tools with the consequence that equity-seeking groups are not measuring up. In this conceptual paper, we argue for theory adaptation (Jakkola, 2020) of the K-12 leadership framework, the Ontario Leadership Framework (OLF). We propose that leadership characteristics, assets, and skills differ from traditional theories, and individuals who belong to equity-seeking groups (e.g., women, Indigenous, Black, Brown, LGBTQ2S+ or those living with a disability). As such, relying only on traditional leadership frameworks is a structural inequity that creates unfair comparisons that have cascading consequences for current and aspiring leaders, students, and school communities. Arguably, those who aspire toward leadership positions and currently hold leadership positions may have different asset-based skills, values, and goals than what current policy states they must have. However, despite the focus on equity, diversity and inclusion in K-12 education, the dominant educational leadership frameworks remain an untouched standard in Ontario, thus creating tension and expectations for all equity-seeking groups to behave in role-congruent ways while suppressing other valuable skills and competencies. In this paper, the authors will offer evidence to support the claim that leaders are constrained in their leadership performance to conform to male, white, leadership expectations. We advocate for the incorporation of equitable, anti-racist, and anti-oppressive promotion of feminist-based leadership theories in K-12 schools.

\section{THE DEFICIT-BASED MEASURING STICK: A SNAPSHOT}

Racialized women and leaders with multiple identities continue to experience prejudice and stereotypes when leading where white men do not, making it challenging when obtaining positions of positional power (Powell, 2011). Leadership philosophy in general, and the application of it, have been conventionally operationalized toward male-oriented leadership behaviours, which has led to an asymmetrical understanding of what effective leadership is (Eagly \& Carli, 2007; Powell, 2011). The leadership field has been intensely focused on and influenced by white men (Belason, 2017).

In looking at gender differences in leadership between women and men alone, Paustian-Underdahl and colleagues (2014) found that women significantly outperformed men in business and education when the women's colleagues and subordinates were the ones to assess leadership efficacy skills. Self-reported leadership effectiveness assessments were found to have no significant differences, yet men and women believed their performances were equal to men (Paustian-Underdahl et al., 2014). Other studies (e.g., Hoyt \& Burnette, 2013; Schock et al., 2019) have found that women are expected to demonstrate superior levels of leadership by displaying competitiveness and toughness, as well as communal behaviour, while also ensuring that women must make sure they are visibly succeeding. However, when women do successfully ascend into C-Suite or senior leadership positions, these leadership behaviours are then viewed negatively. In this way, conforming to a male-set-standard can work against these women by resulting in lower payfor-performance bonuses (Kulich et al., 2007), glass cliff assignments (Ryan et al., 2007), and increased instances of discrimination stemming from behaving in a manner that violates traditional gender norms (Eagly \& Karau, 2002; Paustian-Underdahl et al., 2014).

\section{LEADERSHIP IN K-12 EDUCATION IN ONTARIO}

Dr. Kenneth Leithwood developed the Ontario Leadership Framework (OLF) in 2012 under contract by the Council of Ontario Directors in Education. The OLF was then adopted as the leadership framework for the Ontario Ministry of Education (OLF, 2013) to govern school policy and practice. The leadership framework is a nested model delineating what leadership should look like at the individual, school, and system levels. The OLF specifies what optimal leadership characteristics a school or system leader needs to master. According to the OLF, system and school leaders need to be proficient with a) setting goals, b) aligning resources and priorities, c) promoting collaborative learning cultures, d) using data, and e) engaging in courageous conversations. Within the OLF, leadership is defined as a "collaborative instructional leadership" and as a "particular type of influence process in which principals and educators 
engage in collaborative work focused on student learning and achievement across grade levels through reflection, dialogue and inquiry" (p. 47). Within the OLF (2013), effective leadership behaviours are categorized as cognitive, social, and psychological Personal Leadership Resources (PLRs).

To our knowledge, the framework has never been empirically evaluated or validated as an effective leadership framework in Ontario to date. That is, there is no way of knowing if a principal or superintendent is demonstrating these expected behaviours effectively connecting leadership behaviour to gains in school improvement and effectiveness. It is possible the reason the OLF does not have an accompanying leadership measurement impact framework is due to the fact that the OLF is comprised of large and diffuse concepts that are not adequately operationalized, thereby lacking a theoretical framework. Further, we contend that the OLF also ignores some of the most fundamental aspects of educational leadership relevant today; antioppression/anti-racism, decolonialism, social justice, ethics, empowerment, and relationship-building. The fact that the OLF is missing these major concepts is problematic and it serves to underscore the point that it was designed by white men for white men.

Leithwood et al. (2020) defended his framework, and stated that further research in "leadership selection, evaluation and development" is needed (p. 15). The OLF includes Personal Leadership Resources, which is intended to provide a set of leadership characteristics to guide principals in understanding what constitutes good leadership behaviour. Leithwood et al. (2020) stated that research is also needed to support their claim that the PLRs are the catalyst behaviours facilitating school improvement changes. Aside from the lack of evaluation studies and empirical research of the OLF, the concepts and language of the OLF do not recognize leader identity.

\section{A SNAPSHOT OF RESEARCH THAT EXAMINED IDENTITY-BASED PRINCIPAL LEADERSHIP IN AN ONTARIO DISTRICT}

A recent qualitative interview study examined principal's decision-making in school improvement in one Ontario district school board (Doan et al. 2020). In this example, the principals were white and female, but this study offers insights into how identity influences leadership behaviour. In the Doan et al. study, on average, female principals expressed making almost three times more decisions and almost five times more intentional improvement actions than males. Furthermore, it was found that female principals were disproportionally assigned to work in high poverty, low achievement schools compared to male principals. The principals in this study described the work in low performing schools as extraordinarily challenging and high risk, with excessive workloads, yet, they also expressed that the work was meaningful and they could see how they were effecting change. The authors found that principals working in low performing schools were told by senior leadership they were placed there because they were good leaders, although some believed it was a punishment. The inconsistent messaging around placement and rationale was centered on the fact that the district offered no benchmarking criteria or rubric about what constituted effective or good leadership. Thus, the decisions and assignments to schools demonstrated a gender bias, based on stereotypes such as, "think-crisis-think-female" producing a structural inequity for women leaders (Ryan et al, 2007). This stereotype is known as the Glass Cliff, whereby women have repeatedly been offered leadership positions in times of crisis, where performance is challenging and success unlikely (Ryan et al., 2011; Ryan et al., 2016). Principals were subjectively assigned to schools by senior leaders without a clear rationale or selection methodology for placements. What was intended to be a thoughtful decision became oppressive as selection was deemed a punishment especially when the efforts and work completed by the female principals in both low performing and high performing schools was only seen through the narrow lens of the OLF and the school board's self-created idea of what good performance was.

The district produced a prescriptive and reductionistic data-driven monitoring framework that excluded the real work the principals were engaging in. Several female principals reported they kept two different school improvement plans - one to demonstrate compliance to the district policy of improvement and a second to record the authentic work they wanted and needed to engage in. In particular, the women expressed feeling overwhelmed with the workload and powerless to make decisions. Doan and colleagues surmised that in organizational cultures where women are implicitly valued differently, they felt compelled 
to work twice as hard and make more decisions, especially in high poverty, low performing schools where the political pressure to succeed was salient. The female principals in the Doan et al. (2020) study spoke of their high workloads and how they had learned to handle the everyday crises occurring in their schools. The workload for these women was also disproportionate given that the organizational culture had been set up in such a way that many women felt they had to double their improvement efforts to meet the needs of the school and comply with district school improvement expectations.

In this context, it is clear that effective leadership behaviour was evident in what the women stated they were doing to improve their schools, yet because the actions and decisions did not fit into the prescribed expectation of the district, much of their effectiveness in school improvement went unnoticed (Doan et al., 2020). The female principals were concerned about keeping an account of what they had done to conform to the compliance-based school improvement strategy instead of focusing on the leadership behaviours that mattered to them. They were fearful and anxious about reprisal if they did not behave in prescribed ways. In summary, this study highlights the fact that the current understanding of educational leadership is fundamentally based on a model that does not fit school or person contexts.

\section{WHERE DO WE GO FROM HERE?}

We propose two research directions. First, leadership theory, concepts, and measurement should be developed where assets and strengths are the dominant competencies sought. Secondly, we also propose that leaders do not share the same identity, and as such, an identity-focused educational leadership framework has to be developed that honours the worldviews and lived experiences of all leaders. That is, we need to situate leadership within an intersectional perspective, as the competencies and assets for those with multiple identities will look different again. In essence, there is no one-size-fits-all leadership model or standard, and it is up to the leader to define their leadership capacity and action according to their viewpoints and context. Accountability for effective leadership can focus on results that are based on goals and change. Criteria for effective leadership can be in teaching leaders how to create their own success criteria by defining and monitoring the connections between their actions and outcomes. Did you do what you said you were going to do based on your vision? What was your vision? What was your plan for accomplishing it? Who is better off as a function of your leadership behaviour? What changed? What improved? What did not work, and why?

To illustrate, Lomotey (2019) qualitatively conducted a systematic study of 57 research studies about Black female principals and concluded that Black women lead differently than white men and white women. Lomotey pointed out that the lived experience of Black female educational leaders have been systematically muted by racism and oppression. Similarly, Robinson et al. (2020) demonstrated in their study how Indigenous women in Nova Scotia were leading in schools. Indigenous female leadership differs from white women and Black women. To show how white women, Black women, and Indigenous women lead, we summarized some of the themes that emerged from the Doan et al. study, Lomotey, and Robinson et al in contrast with the current OLF leadership framework in Ontario. This comparison is only a starting place, and by no means is it comprehensive or exhaustive. As can be seen in Table 1, there are stark differences in how women lead compared to the male, white standard in Ontario. 
TABLE 1

AN EDUCATIONAL LEADERSHIP COMPARISON OF TRADITIONAL, FEMINIST, AND INTERSECTIONAL FRAMEWORKS

\begin{tabular}{|c|c|c|}
\hline $\begin{array}{l}\text { Current Traditional Leadership } \\
\text { (i.e., Ontario Leadership } \\
\text { Framework, Ontario Ministry of } \\
\text { Education, 2013) }\end{array}$ & $\begin{array}{c}\text { Feminist Leadership } \\
\text { Competencies based on Feminist } \\
\text { principles } \\
\text { (e.g., Doan et al. 2020) }\end{array}$ & $\begin{array}{l}\text { Intersectional and Contextual } \\
\text { Feminist Leadership } \\
\text { Black } \\
\text { (e.g., Moorosi et al., 2018) } \\
\text { Indigenous } \\
\text { (e.g., Robinson et al., 2020) }\end{array}$ \\
\hline $\begin{array}{cl}\text { - } & \text { Setting goals } \\
\text { - } & \text { Aligning resources with } \\
\text { - } & \text { Promoting collaborative } \\
& \text { learning cultures } \\
\text { - } & \text { Using data } \\
\text { - } & \text { Engaging in courageous } \\
& \text { conversations } \\
\text { Personal Leadership Resources } \\
\text { Cognitive Resources } \\
\text { - Problem-solving } \\
\text { - } \text { Knpertise } \\
\text { Schowledge about } \\
\text { conditions with direct } \\
\text { effects on student } \\
\text { learning } \\
\text { Social Resources } \\
\text { - Perceive emotions } \\
\text { - Manage emotions } \\
\text { - Act in emotionally } \\
\text { Psychological Resources } \\
\text { - Optimism } \\
\text { - Self-efficacy } \\
\text { Resilience } \\
\text { Proactivity }\end{array}$ & $\begin{array}{l}\text { - } \text { Anti-oppressive } \\
\text { - } \text { Understands issues of } \\
\text { - } \text { Fower } \\
\text { purpose } \\
\text { - } \text { Focus on student and } \\
\text { staff well-being } \\
\text { - Inspiring shared vision } \\
\text { and action } \\
\text { - } \text { Reflection } \\
\text { - Unlearning patriarchal } \\
\text { structures and } \\
\text { - } \text { Inpectations } \\
\text { - } \text { heart, spirit and body } \\
\text { - Comical } \\
\text { - } \text { Female mentorship }\end{array}$ & 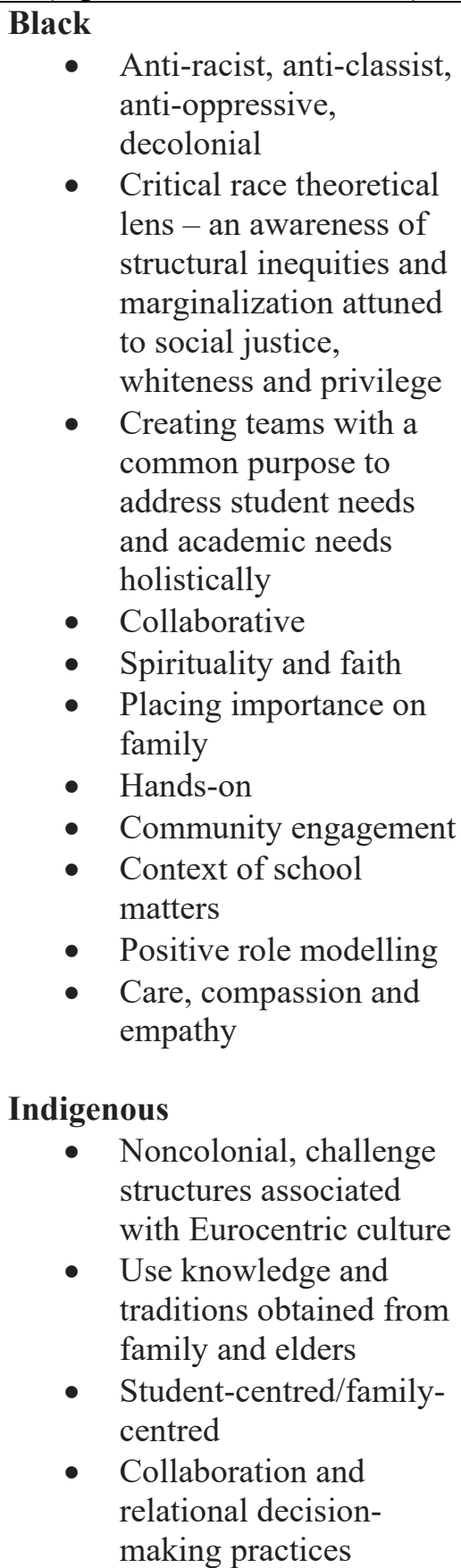 \\
\hline
\end{tabular}




\begin{tabular}{|c|c|c|}
\hline & & $\begin{array}{ll}\text { - } & \text { Preservation of } \\
\text { Aboriginal culture and } \\
\text { worldview } \\
\text { - } & \text { Presence of spirituality } \\
\text { - } & \text { Return to the land } \\
\text { - } & \text { memmunity } \\
\text { membership and } \\
\text { community } \\
\text { empowerment } \\
\text { - Networking and } \\
\text { mentorship } \\
\text { Lead by example of } \\
\text { how to live a good life } \\
\text { according to cultural } \\
\text { values and teachings }\end{array}$ \\
\hline $\begin{array}{l}\text { Current Knowledge Gathering } \\
\text { of Leadership Impact }\end{array}$ & $\begin{array}{l}\text { Feminists Knowledge Gathering } \\
\text { of Leadership Impact }\end{array}$ & $\begin{array}{l}\text { Intersectional Knowledge } \\
\text { Gathering of Leadership Impact }\end{array}$ \\
\hline \multirow[t]{2}{*}{$\begin{array}{l}\text { Quantitative, 360- } \\
\text { degree data collection } \\
\text { - Standardized surveys } \\
\text { and use of personality } \\
\text { inventories } \\
\text { - Student outcomes are } \\
\text { used as proxies of good } \\
\text { leadership, such as } \\
\text { student performance on } \\
\text { standardized tests and } \\
\text { grades }\end{array}$} & $\begin{array}{l}\text { Qualitative data } \\
\text { collection preferred } \\
\text { Modified case studies } \\
\text { using narratives, open- } \\
\text { ended survey or } \\
\text { observational methods } \\
\text { with thematic analysis } \\
\text { - Co-designed surveys } \\
\text { that are participative and } \\
\text { shared } \\
\text { - Knowledge-exchange } \\
\text { opportunities }\end{array}$ & $\begin{array}{l}\text { Black } \\
\text { Storytelling, counter- } \\
\text { stories, and dialogue } \\
\text { using a) critical race } \\
\text { theory to address } \\
\text { privilege and whiteness, } \\
\text { b) standpoint theory to } \\
\text { address how to } \\
\text { overcome oppression } \\
\text { and decolonial ideology } \\
\text { and to acquire } \\
\text { knowledge as analytical } \\
\text { methods }\end{array}$ \\
\hline & & $\begin{array}{l}\text { Indigenous } \\
\text { - Conversations and } \\
\text { stories } \\
\text { - } \\
\text { Participative, respectful } \\
\text { knowledge sharing } \\
\text { sessions without rigid } \\
\text { agenda or structure } \\
\text { - } \text { Dependent on each } \\
\text { Indigenous } \\
\text { communities' ways of } \\
\text { knowing and pedagogy }\end{array}$ \\
\hline
\end{tabular}

In terms of evaluating leadership efficacy in schools or within systems, there are many useful qualitative and mixed-method examples of leadership research established in the literature with peer-reviewed methods and analyses to build on (e.g., Klenke, 2016). We believe it is possible to elucidate what principals do and connect their leadership behaviour to an identity-based leadership framework, and make connections to school improvement changes. We call on scholars and practitioners to create a framework of understanding as the first step in creating an identity and asset-based framework for effective educational leadership. We would love to see the creation of a common repository of what works in Ontario education by compiling 
the stories of leadership and how they lead that can be searched by identity or types of leadership by selfassessed identity and school context (i.e., school community assets or demographics) to begin to develop patterns of leadership. The leadership contributions of women and racialized women are especially long overdue.

\section{RECOMMENDATIONS FOR FUTURE RESEARCH}

Future research in this area would need to take great care in ensuring a balanced review of principal leadership, as the elucidation of what is not working is just as relevant to learn from as the successes. In learning what mistakes were made, or lessons learned, we can also hope to avoid positive results publication bias. We call on others in support of this endeavor, as authors of this paper, we are both white and as such can only contribute to part of the development of an identity-based and flexible framework. We need to include multiple voices and multiple identities. There needs to be more leadership choices and these choices need to be seen and given the opportunity to flourish. In pushing educational policy from the ground up, we cannot afford to wait for the government of Ontario to set policy, instead we must take lead within our K-12 school boards and aggressively share and publish the work. According to Dr. Ann Lopez, "A focus on of educational leadership is influencing policy creation at government levels and implementing policies at the school level. These conversations must include decolonizing approaches" (2020, p. 45). Lopez states that educational leadership is about changing school experiences that are rooted in regimes of power and knowledge that serves to marginalize students. Thus, a social justice rationale towards acting now and updating how we think and lead in schools is a moral imperative and a human rights issue.

Future development of an identity and asset-based framework also needs to consider the perils of meritocratic belief systems that underpin inequities in work, income, education, family, economics, and government (Markovitis, 2019). Meritocracy is the trap that sets leaders up to accept traditionally malecentric, colonial leadership paradigms. The ideology that hard work levels the playing field overshadows the nefarious role of privilege.

An identity and asset-based leadership model is resonant of feminist-based leadership as they both conceptually share a focus on anti-oppression ideology as well as an emphasis on understanding issues concerning power. It also emphasizes sharing a purpose, inspiring shared visions, reflection, learning and unlearning, and empowering and enabling others while integrating the mind, heart, and body (Wakefield, 2017). An identity and asset-based educational leadership framework must emphasize issues of power by equipping leaders with the capacity to address structural inequities in policy, practice, governance, and organizational politics. We have shown here that the language of educational leadership in Ontario is devoid of anti-oppression and decolonization concepts and language. We are calling on all leaders to reform educational leadership and help each other with research and practice on how to recognize identity-based knowledge and viewpoints to challenge norms, raise concerns about power, navigate and combat internalized racism, sexism, classism, ableism and homophobia, while promoting ethics and social justice orientation for transformative change. In summary, educational leadership, especially in our K-12 school systems, is in dire need of a research program focusing on identity-focused, asset-based philosophy. We have learned that one-size does not apply or fit all when it comes to curriculum delivery, assessment, and resourcing of schools. The question remains, why have we not applied the same equitable thinking to our leadership models, training, and expectations?

Within the field of K-12 education, we have presented the idea that HERLeadership as a social and ethical imperative for researchers and policy-makers. However, HERLeadership as a gender parity-seeking framework is also a good economic investment. Diversity, Equity, and Inclusion (EDI) education training programs are a multi-billion-dollar industry in both profit and non-profit sectors. Many of these programs fail to meet performance expectations and targets due to poor program implementation and evaluation efforts, which exacerbate gender and racial disparities (Dobbin \& Kalev, 2018). Any business that invests in an EDI strategy that ignores leadership philosophy, processes, and programs without critically evaluating the core values, beliefs, and behavioural expectations important to the groups they hope to impact may not see a healthy return on investment. 


\section{REFERENCES}

Bass, B.M., \& Avolio, B.J. (Eds.). (1994). Improving organizational effectiveness through transformational leadership. Sage.

Bass. (1998). The ethics of transformational leadership. In J.B. Ciulla (Ed.), Ethics: The heart of leadership (pp. 169-192). Quorum.

Belason, A.T. (2017). Women in management. A framework for sustainable work-life integration. Routledge.

Canadian Women's Foundation. (2019, May). The facts about the gender pay gap in Canada. Retrieved from https://canadianwomen.org/the-facts/the-gender-pay-gap/

Doan, B., Martinovic, D., Flessa, J., Kane, D., Chambers, J., \& Smith, K. (2020). The Role of bounded rationality in school improvement. [Doctoral Dissertation, University of Windsor]. ProQuest Dissertations Publishing. http://search.proquest.com/docview/2413917558/2020). The Role of bounded rationality in school improvement. University Dissertation.

Dobbin, F., \& Kalev, A. (2018). Why doesn't diversity training work? The challenge for industry and academia. Anthropology Now, 10(2), 48-55.

Eagly, A.H., \& Carli, L.L. (2007). Through the labyrinth. Harvard Business School Press.

Eagly, A.H., \& Karau, S.J. (2002). Role congruity theory of prejudice toward female leaders. Psychological Review, 109, 573-598.

Gender and Economy. (2021). The Gender Wage Gap. Retrieved from https://www.gendereconomy.org/gender-pay-gap-at-the-top/

Hoyt, C.L., \& Burnette, J.L. (2013). Gender bias in leader evaluations: Merging implicit theories and role congruity perspectives. Personality and Social Psychology Bulletin, 39(10), 1306-1319.

Jakkoka, E. (2020). Designing conceptual articles: Four approaches. AMS Review, 10, 18-26.

Klenke, K. (2003). Gender influences in decision-making processes in top management teams. Management Decision, 41(10), 1024-1034.

Leithwood, K., Harris, A., \& Hopkins, D. (2020). Seven strong claims about successful school leadership revisited. School, Leadership \& Management, 40(1), 5-22.

Lomotey, K. (2019). Research on the leadership of Black women principals: Implications for Black students. Educational Researcher, 48(6), 336-348.

Lopez, A.E. (2020). Decolonizing educational leadership. Exploring Alternative Approaches to Leading Schools. Palgrave MacMillan,

Milville, M.L., \& Ferguson, A.D. (Eds.). (2014). Handbook of Race-Ethnicity and Gender in Psychology. In M.B. McRae \& S.I. Dias, In the boardroom/out of the loop: Group and organizational dynamics.

Ministry of Education Ontario. (2013). Ontario leadership framework. Retrieved from https://www.educationleadership-ontario.ca/application/files/8814/9452/4183/Ontario_ Leadership_Framework_OLF.pdf

Moorosi, P., Fuller, K., \& Reilly, E. (2018). Leadership and intersectionality: Constructions of successful leadership among Black women school principals in three different contexts. Management in Education, 32(4), 152-159.

Paustian-Underdahl, S.C., Walker, L.S., \& Woehr, D.J. (2014). Gender and perceptions of leadership effectiveness: A meta-analysis of contextual moderators. Journal of Applied Psychology, 99(6), $1129-1145$.

Powell, G.N. (2011). The gender and leadership wars. Organizational Dynamics, 40, 1-9.

Robinson, I.M., White, R.E., \& Robinson, D.B. (2020). Indigenous women in educational leadership: Identifying supportive contexts in Mi'kmaw Kina'matnewey. International Journal of Leadership in Education, 23(6), 691-711.

Ryan, M.K., Haslam, A.S., Morgenroth, T., Rink, F., Stoker, J., \& Peters, K. (2016). Getting on top of the glass cliff: Reviewing a decade of evidence, explanations, and impact. The Leadership Quarterly, $27,446-445$. 
Ryan, M.K., Haslam, S.A., Hersby, M.D., \& Bongiorno, R. (2011). "Think crisis-think female": The glass cliff and contextual variation in the think manager-think male stereotype. Journal of Applied Psychology, 96(3), 470-484.

Schock, A.K., Gruber, F.M., Scherndl, T., \& Ortner, T.M. (2019). Tempering agency with communion increases women's leadership emergence in all-women groups: Evidence for role congruity theory in a field setting. The Leadership Quarterly, 30, 189-198.

Wakefield, S. (2017). Transformative and feminist leadership for women's rights. Oxfam America Research Backgrounder Series. Retrieved from https://www. oxfamamerica.org/explore/res

World Economic Forum (2021). The Global Gender Gap Report. Retrieved from http://www3.weforum.org/docs/WEF_GGGR_2021.pdf 